\title{
EVALUATION OF THE FARMERS' WOODLOT COMPONENT OF THE PARTICIPATORY FORESTRY PROJECT IN SRI LANKA
}

\author{
M W M W T B Dissanayake \\ Upper Watershed Management Project
}

The farmers" woodlot component of the Participatory Forest Project in Sri Lanka has a duel concern: environmental rehabilitation by creating woodlots in marginal slate lands with the participation of local people, and socio-economic upliftment of the rural poor. Based on the mixed perfornance of the project during the last few years, this study tried to examine the level of rural participation in the project, and the effect of major conditions and their delerminant factors on successful establishment of the woodlots.

The field study was carried out in the central part of Sri Lanka, during the period from July to September 1997. Two successful and two unsucessful project sites were selected in the Badulla and Kandy districts based on the seedling survival rate as the main criteria for evaluating success. Data collection was mainly hased on series of discussions and semi-structured interviews carried out with project participants, non-participants, key informants, and project olficials. In addition supporting secondary data was collected by reviewing the project related reports and documents, and infonnal interviews with project ofticials.

The study reveals that the majority of initial decisions related to the project such as, initial decision on a woodlot project, selection of project's location, land distribution, planting design are primarily laken by the project officials. Local people are involved with decisions related to the selection of participants and species. The majority of ongoing decisions such as, weeding and maintenance regime, application of fertilisers, are also imposed by the project. All decisions related to intercropping are taken by the locial people.

Among the resources required lor implementation, land, lechnical knowledge, and material inputs such an, tree scedlings, fertilisers, are provided by the project, whereals participants contribute labour, indigenous knowledge, and inputs for intercroppings. A food aid incentive has been used to compensate the labour investment of participants. Local peoples' involvement in administration and coordination of the project at village level is limited.

Three conditions for the success of woodlots are considered in detail. The first concems the site characteristics, of which, site arability, proximily and accessibility, and tenurial status are the three important determinant factors for success. Among them, site arability appeared to be the most importint factor.

Among the different plantation establishment techniques used in the project, sclection of the most suitable tree species for the project's location, planting design and spacing based on participant's preference for intercopping, location specific weeding and maintenance regine, adequate measures for protection, are detenninant factors for the success.

Four types of incentives used in the project appeared to be crucial for the success. They are, issue of free tree seedlings, food aid coupons, lease agreements, and the provision of technical assistance. The issue of fertilisers was not a condition for suceess as it was not based on site specific needs. 